【論 文】

UDC : $72.03: 728.6$

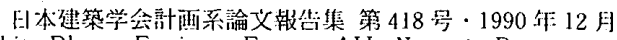
Journal of Archit. Plann. Environ. Engng, AIJ, No.418, Dec., 1990

\title{
日光社参史料からみた江戸時代の民家の主屋規模・平面と 階層構成・家族人数の関係
}

THE RELATION BETWEEN THE SCALE OF THE FARM HOUSES (THE PLAN. NING FORM) AND HIERARCHY (THE FAMILY INSTITUTION) IN THE EDO PERIOD FROM THE HISTORICAL MATERIALS OF NIKKOU SHASAN 7

\author{
津田良樹* \\ Yoshiki TSUDA
}

\begin{abstract}
The object of this paper is to consider the relation between the scale of the farm houses or the planning form and hierarchy or the family insutitution from the record with Ezucho.

On the Kami-Kanai village in the Meiwa-ki (1764-1772) and Kami-Yokota or Yaita village in the Tenpo-ki (1830-1844), the scale of these farm houses was tended to enlarge with the increase of the Mochidaka.

By the relation between hierarchy and the planning form, during from the Kyoho-ki (1716-1736) to the Tempo-ki, the type of Hiromagata was distributed from low level to high level. The type of Yomadori was found in the high level of the Kami-Yokota and Yaita village in the Tempo-ki. There is not any relations between the members of the family and the scale of the farm houses.
\end{abstract}

Keywords : farm houses, scale, planning form, hierarchy, family institution, historical material, Nik-* kou shasan

\section{はじめに}

徳川将軍が日光に参詣する日光社参は，将軍が軍団編 成を取る大勢の供侍をしたがえ，日光御成街道・日光街 道を通り日光に至っている。その間，将軍の宿泊地は岩 梘・古河・宇都宮であり，将軍に供奉する供侍たちは将 軍の宿泊地周辺の村々に下宿 ${ }^{1}$ している。そのため村々 では村内の住居の平面を調べた住居絵図帳を作成し，幕 府に提出している。それら住居絵図帳のなかで農村に係 る帳簿を，現在までに 19 冊見いだしている。19 冊の住 居絵図帳をもとに，主屋規模と平面形式についての検討 は既に前稿で報告した2)。本稿では，前稿に引き続き住 居絵図帳3を中心に，関連文書を併せ，階層構成および 家族人数と主屋の関係などについて検討する。

住居絵図帳には居住者名に村方三役の役名および百 姓・水吞の別などを肩書することはあるが，持高や家族 構成まで記されることはない。ここでは，関連文書から 住居絵図帳の作成当時の階層を識別する指標として, 各 Fの持高が判明する場合を取り上げ，持高による階層棈 成と主屋の関係について検討する4!。また，宗門帳など から居住者の家族構成が判明する場合を取り上げ，家族 人数と主屋との関係についても検討する。

\section{1. 階層構成と主屋}

\section{1-1＼cjkstart享保期岩原村の階層構成と主屋}

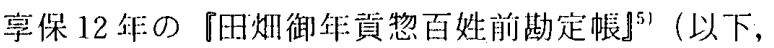
『勘定帳』と略記する）上り，岩原村の各戸の持高が判 明する。この中には寺および東新里村と肩書きされる 1 軒が含まれており，これらを除外すると27.軒である。 享保 12 年の岩原村住居絵図帳と『勘定帳』とを対照す ると 23 名の名前が一致する。また，敦保 3 年の『宗門 御改帳』を件せ検傠すると『勘定帳』に分けて書き上 げられている浅右衛門, 伊右衛門の 2 名は太郎右衛門家 の家族で，住居絵図帳では太郎右衛門 1 軒に当たり7， また，『勘定帳』の作左衛門は住居絵図帳の権兵衛に当 たる ことが判明する。これらの検討をもとに，岩原村 における主屋規模と持高との関係を図一1に示す。

階層構成は，無高から，最大 30 石余まてである。30石 余は庄屋で特に多い。この生屋を別にすると，無高から 15石ほどの間に分布している。内容は，無高層が 9 軒, 4 石台までが 2 軒，5－9石台の持高層が最も多く16 軘 あり，次いで 10〜14 石台の層が 6 軒と続く。

主屋規模と持高との関係は，持高と坪数の間には一定 の対応関係は認められない。しかし，分地百姓でかつ無 
持高

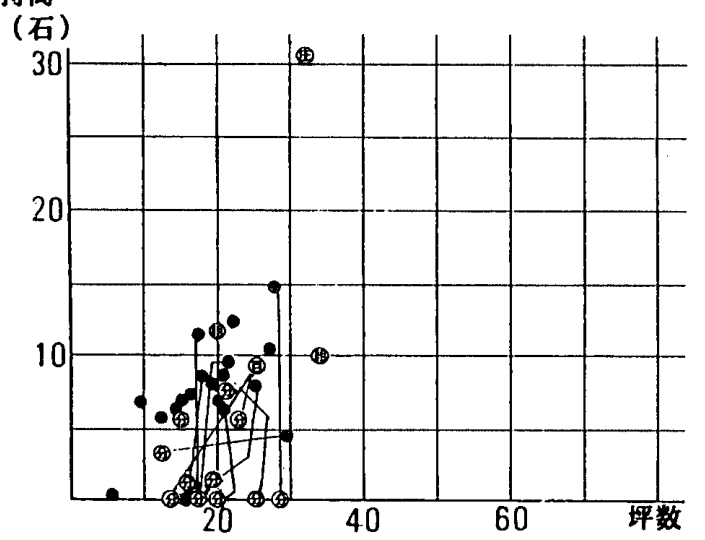

(坪)

図一1享保期岩原村主屋規模（坪数）と持高

生：生屋, 組 : 組頭, 百: 百姓代, 分: 分地百姓（結ん だ線は，本家・分地関係を示す)。

高の 8 軒の主屋は 16 坪から 29 坪あり，いずれも持高の 多い百姓からの分地で，実質的にはそれ相応の持高が あったのではないかと推测される。これら 8 軒を除外し てみれば，持高と坪数との間にある程度相関があるよう にみえる。しかし，無高で 29 坪あるいは 25 坪ほよ゙の主 屋もあり，一方，11 石余の持高で 17.5 坪ほどの主屋も ある。

分棟型と階層との関係は，持高が多い層に分棟型が多 い。例外ではあるが，無高あるいは持高 5 石ほよ゙の分地 百姓で分棟型の 3 軒は, その本家もまた分棟型である(図 -2 , 図 -3$)$ 。

平面形式と階層の関係は, 居室 1 室だけの単室住まい の 1 軒は無高であり，土間と 1 部屋からなる一間取の 3 軒はそれぞれ無高・ 3.3 石持・5.8 石持で，単室住まい および一間取は持高の低い層に属している。29軒を占 める広間型（広間型を基本に裏部屋などを拡張したもの を含む) は，無高から 30.8 石（庄屋）までに分布し， 持高との関係は顕著ではない。すなわち，享保期の岩原

\section{持的}

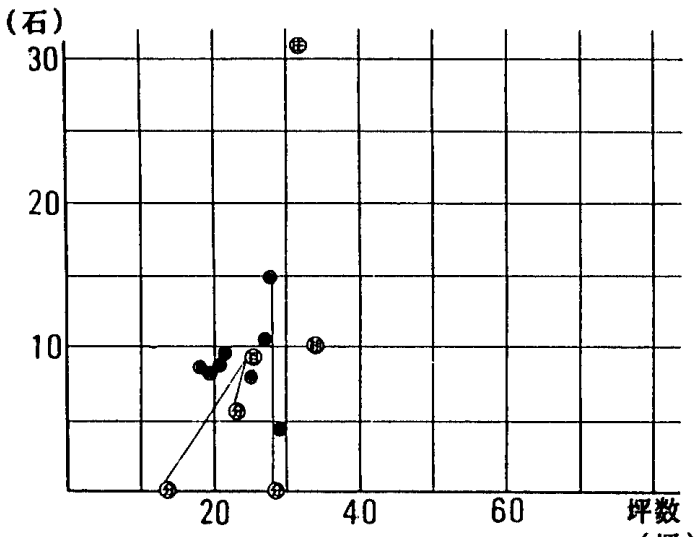

図一2 享保期岩原村分棟型の主屋規模（坪数）之持高

生：生屋, 組：組頭, 百：百姓代, 分：分地百姓（結ん だ線は，本家・分地関係を示す)。
(石)

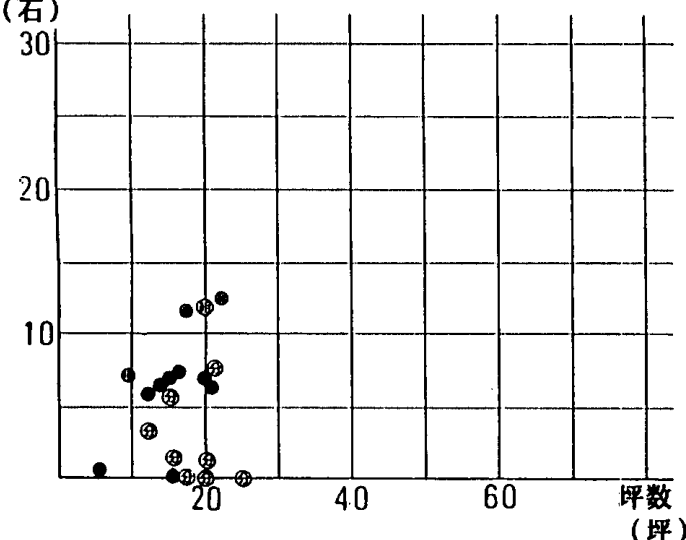

(坪)

図一3 享保期岩原村非分棟型の主屋規模（坪数）上持高 左：生屋, 組：組頭, 百：百姓代, 分：分地百姓

村では単室住まいおよび一間取は持高の低い檿に属す が，広間型は階層差に関係なく分布している。

\section{1-2 明和期上金井村の階層構成と主屋}

明和 8 年の上金井村『田畑御年貢算用帳 $\rfloor^{(0)}$ 上り，上 金井村のそれぞれの百姓の持高が判明する。さらに，『五

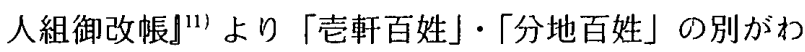
かる。これらをもとに主屋坪数と持高等との関係を図4 に示す。生屋は持高・坪数ともに特に大きく，持高が 30 石余, 主屋坪数が 70.5 坪ある。

持高は，4石台までが 1 軒，5－9石台が 13 軒，10 14 石台が 15 軒, 15 19 石台が 2 軒, 30 石余が 1 軒で ある。5〜14 石台の間に 32 軒中 28 軒が分布している。 当村においては分地百姓でも5１0石ほどの持高が陊 い。

主屋規模は, 9 坪台までが 2 軒, 10 19 坪台が 7 軒, 20 29 坪台が 14 軒, 30 〜 39 坪台が 5 軒, 40 - 49 坪台 が 3 軒， 70.5 坪が 1 軒である。坪数において本百姓と 分地百姓の間に大きな格差は認められない。

持高と坪数との関係は，例外もあるが，持高弲 5 石ほ ビ増加すれば坪数が 10 坪ほど増加するという比例関係

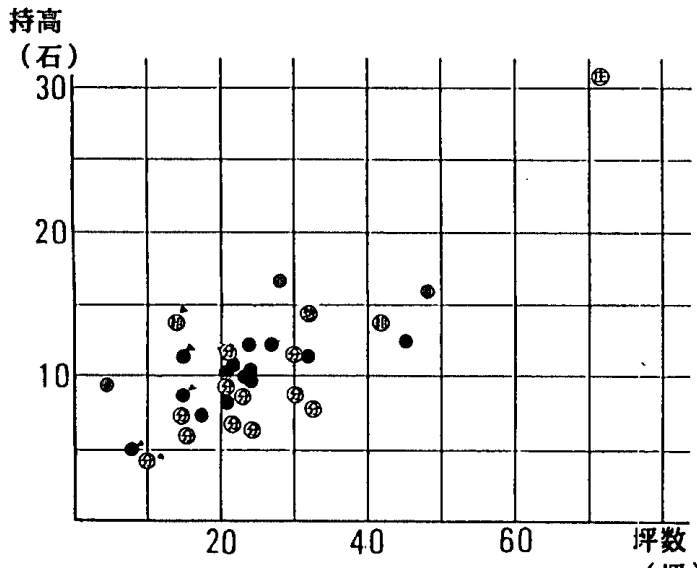

図一4 明和期上金井村主屋規模（坪数）之持高

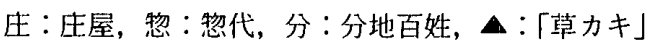


が認められる。

小規模主屋には壁を「草力キ」121にする場合が多いが, 「草力キ」の主屋に住む者でも14 石あるいは11 石ほよ゙ の持高の場合もある。組頭の内の 1 人は，14石ほよ゙の 持高があるにもかかわらず，「草力キ」の 12.5 坪の小規 模な主屋に住んでおり，他の村などの例に較べて異例で ある(3)。

平面形式と階層との関係についてみれば，一間取およ び二間取の 11 軒には 4.4 石・5.1石の当村では最も少 ない持高層の主屋が含まれるだけでなく, 11.4 石・ 13.8石など中位の持高層の主屋も含まれている。また， 広間型に較べ持高の割に坪数が少ない傾向がある（図一 $5)$ 。

20 軒を占める広間型には, 持高 6.7 石から 30.1 石ま での広い階層の主屋が含まれている。また，全体的に持 高の割に坪数が多い傾向がある（図一6）。なお，喰違四 間取の 1 軒は 45 坪で 12 石余の持高である。

以上のように，一般に持高と平面形式との間に一定の 対応関係は認められない。

\section{1-3 明和期高谷林新田村の階層構成と主屋}

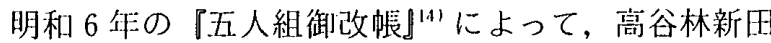

\section{持高}

(石)

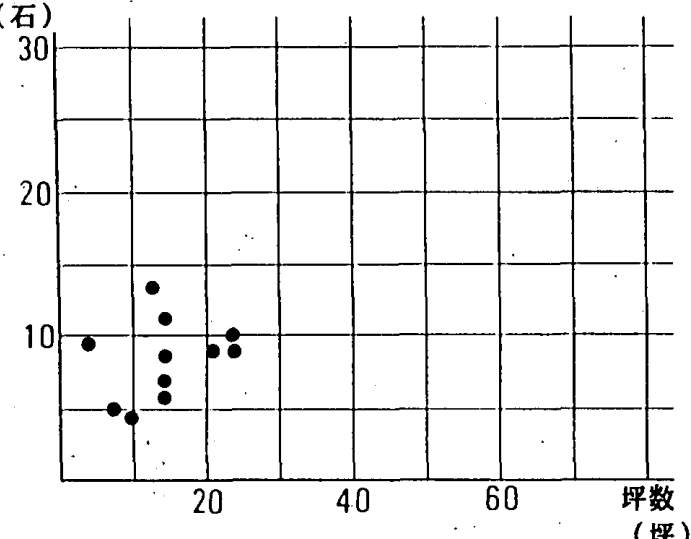

(坪)

図一5 明和期上金井村一間取・二間取の主屋規模（坪数）と持 高

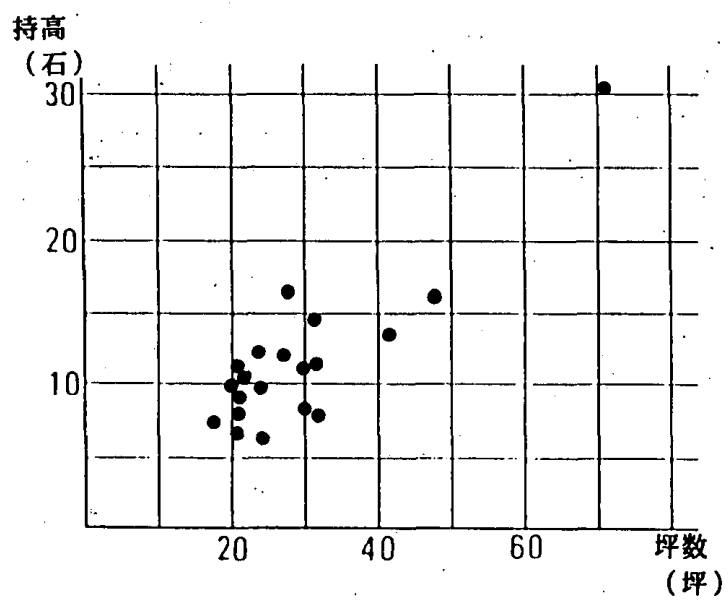

図-6 明和期上金井村広間型の主屋規模（坪数）之持高
持高

(石)

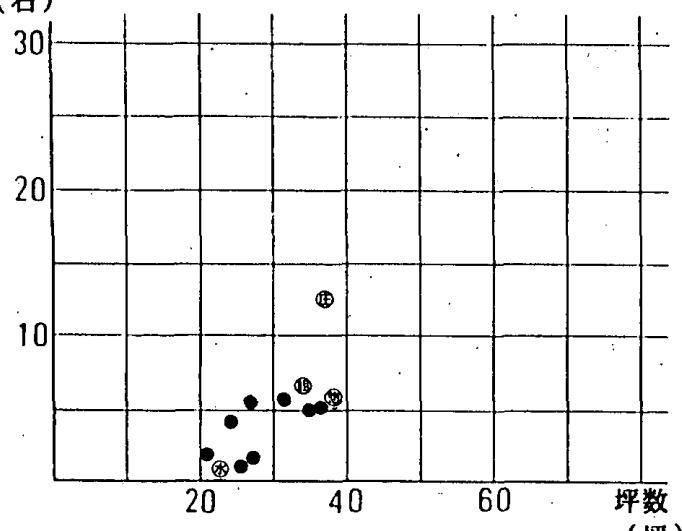

(坪)

图一7 明和期高谷林新田村の主屋規模（坪数）之持高 生：生屋, 組：組頭，惣：惣代，水：水吞

村の百姓および水吞の持高がわかる。住居絵図帳から算 定した主屋坪数と持高との関係を図一7に示す。

持高は，4〜7石台に 12 軒中 7 軒が集中している。 12.5 石持は庄屋で，当村において.はとびぬけて持高が 多いが，近村の岩原村・上金井村等に較べるとはるかに 少ない。寛文期に新田開発が始まったが，その後も水に 恵まれず，開発が進まなかったためであろう ${ }^{151}$ 。当村内 における階層差は比較的小さい。

坪数は, 最大 38.5 坪加最小 21.25 坪の間の狭い範 囲に分布している。

持高と坪数との関係は，持高の最も多い12.5 石の生 屋の主屋が規模においては 2 番目の広さであり，一方， 無高の水吞の主屋が 23.25 坪ほどあって，最小規模では ない点が注目される。しかし，格差は小さいが，持高と 坪数之がある程度相関している。すなわち，あえていえ ば 5〜6石層は 25〜40坪ほど，2石以下の層は 20〜 27 坪ほどの範囲にある。

平面形式は，生屋の主屋が土間沿いの広間（高谷林新 田村住居絵図帳では「台所」）の後側に奥行 1 間ほどの 寝間を配した四間取となるほか，残る 11 軒はいずれも 広間型である。そのため，庄屋の主屋を別にすれば，持 高には関係なく広間型で, 階層差による平面形式の変化 はみられない。

\section{1-4 文政期田中村の階層構成と主屋}

文政期国中村の百姓の持高は，文政 13 㑋の『五人組 御改帳 $ل^{(6)}$ よりわかる。しかし，住居絵図帳は文政 6 年 ごろと考えられ，6〜7年の年代差があり，24 軒中 9 軒 の名前が一致しない。しかし, 文政 6 年の『宗門御改 帳』年を併せて検討することによって，その内の 7 軒は 同一家系であることを考定することができる。それでも 不明な 2 軒は検討から除外している ${ }^{181}$ 。坪数と持高との 関係を図-8に示す。

持高は，4 石台以下が 2 軒，5－9石台が 7 軒，10〜14 石台が 9 軒，15 19 石台が 4 軒である。 
持高

(石)

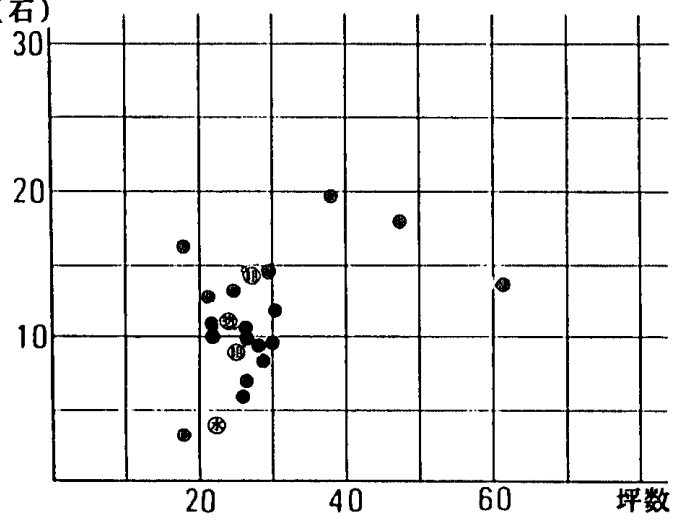

(坪)

図一-8 文政期田中村の主屋規模（坪数）之持高 組：組頭,惣：惣代, 水：水吞

坪数は, 特に大きい 3 軒を除けば 18 - 30 坪の範囲に ある。

坪数と持高との関係は, 持高が多くなると坪数が大き くなる傾向は窺えるが，両者の間に強い相関は認められ ない。

平面形式亡階層との関係についてみると，広間型は持 高 3 石ほどの水吞を含め持高 3 石台から 16 石台までの 幅広い範囲に分布している（図一9）。

土間沿いの広間後側に寝間を設ける四間取は，4石台 以下にはないが，6石持でもこの型の主屋もあり，一概 に持高の多い層にこの型が多いともいえない。むしろ， 大規模な主屋にこの型が多いといえよう(図一10)。なお， 一間取と二間取のそれぞれ 1 軒は持高不明のため分布図 では省いている。これら2軒は文政 13 年には「潰百姓」 となっており，文政 6 年当時すでに経済的に行きづまっ ていたと推測される。

\section{1-5 天保期上横田・屋板村の階層構成と主屋}

天保 13 年の住居絵図帳より 4 年後にあたる弘化 3 年 の『村高銘々持高潰高書上帳」年1 より，上横田・屋板村 の各戸の持高がわかる。しかし，4 年の年代差があるた めか, 寺および隠居を除く 45 軒のうち 3 軒は該当する

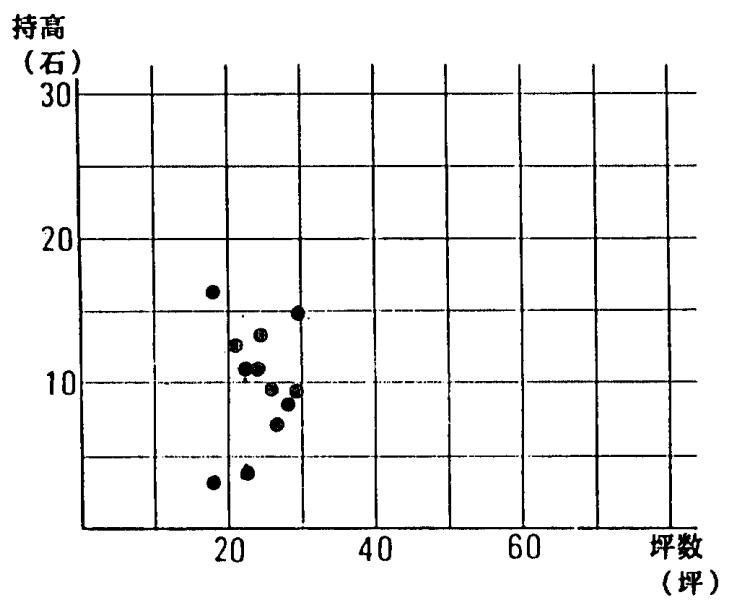

図一9 文政期田中村の広間型主屋規模（坪数）と持高
持高

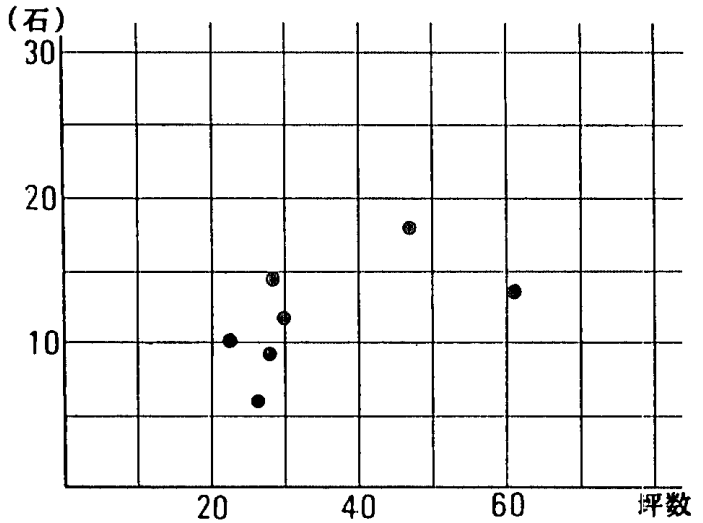

(坪)

図一10 文政期出中村の広間後側に寝間を配する四間取の主屋 規模 (坪数) と持高

名前が見当たらず，ここでは検討から省いている。住居 絵図帳から算定した坪数と持高の関係を図一11に示す。 上横田・屋板村は持高・坪数ともに前記の 4 村に較べは るかに大きい家が多い。

持高は 4.5 石から 69 石ほよ゙の間に分布しており，10 〜20石に 18 軒が集中している。

坪数は, 最小 6 坪から最大 106.25 坪の間に分布し, 30ー35 坪に 12 軒が集中している。

持高と坪数との関係は，持高が 10 石に満たないにも かかわらず， 32 坪・ 34 坪・36 坪ほどの主瘫を所持する 場合もあれば，逆に，14 石・20石ほどの持高があるに もかかわらず，10坪に満たない主屋しかない場合もあ

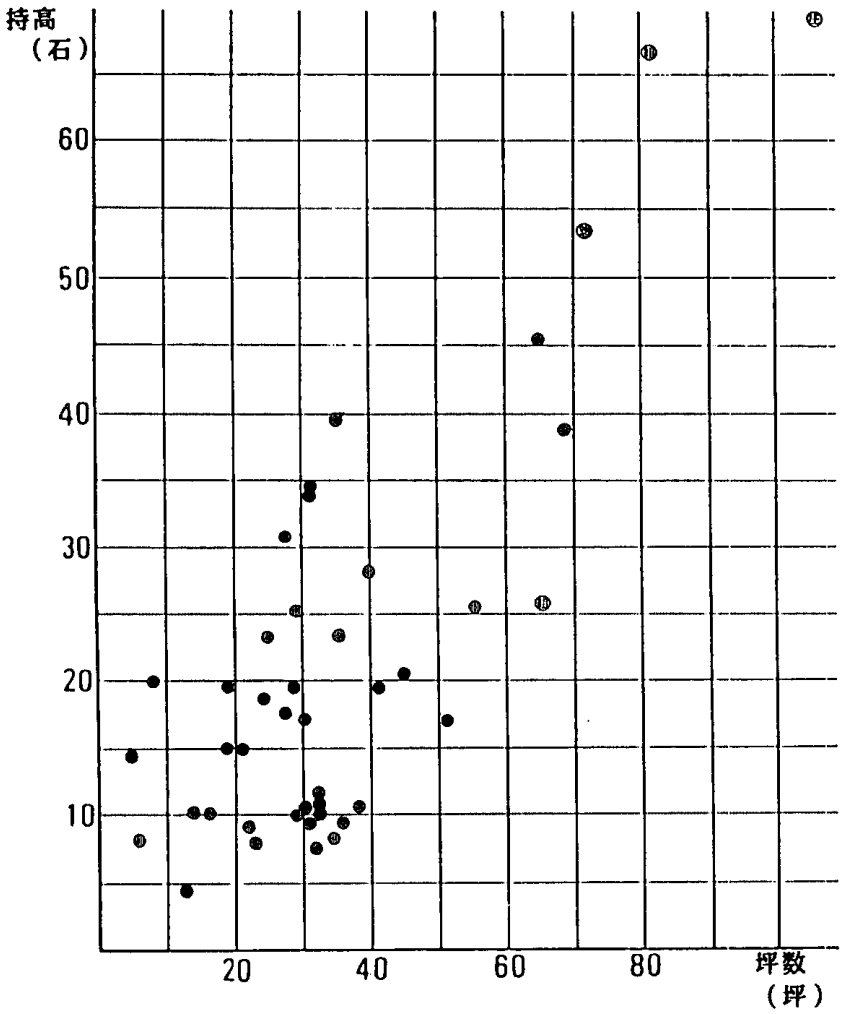

图一11 天保期上横田・屋板村の主屋規模（坪数）亡持高 生：圧屋, 組：組頭,惣：惣代 
る。しかし，それら例外を除けば，持高が多くなるにつ れて主屋坪数も大きくなる傾向が上金井村などに較べて 顕著である。村役人層のうち庄屋など 3 軒は持高・坪数 ともに際だって大きい。残る組頭の 1 軒も 26 石余の持 高で 66 坪の主屋である。

平面形式と階層との関係についてみると，一間取の 2 軒は 8 石余および 14 石余である。

広間型（広間型を基本に裏部屋などを拡張したものを 含む）は 42 軒のうち 30 軒を占めており，この 30 軒は， 持高の最も少ない 4.5 石から 40 石の間に幅広くみられ る $($ 図-12)。

四間取の 9 軒はすべて 20 石以上である。特に 40 石以 上の 4 軒はいずれも四間取である（図一13）。

すなわち, 当村の百姓の主屋は広間型が一般的で, 持 高 20 石以上の層では四間取が多くなり，40石以上はす べて四間取になる。一方，一間取も少数ではあるが存在 している。

1-6 小 結

以上，持高の明らかになる岩原村，上金井村，高谷林 新田村, 田中村，上横田・屋板村について持高と分棟型・ 主屋規模・平面形式なよ゙の関係を検討した。

分棟型は享保期の岩原村で 4 割ほどみられ，以降の各 村では全くみられず，階層構成との関係では，持高が多 い層に多いことが判明した。例外ではあるが，無高ある いは 5 石ほよ゙の分地百姓で分棟型の場合があり，ここの場 合はその本家が分棟型であることも明らかとなった。

階層構成と主屋規模についてみると，持高が増加する

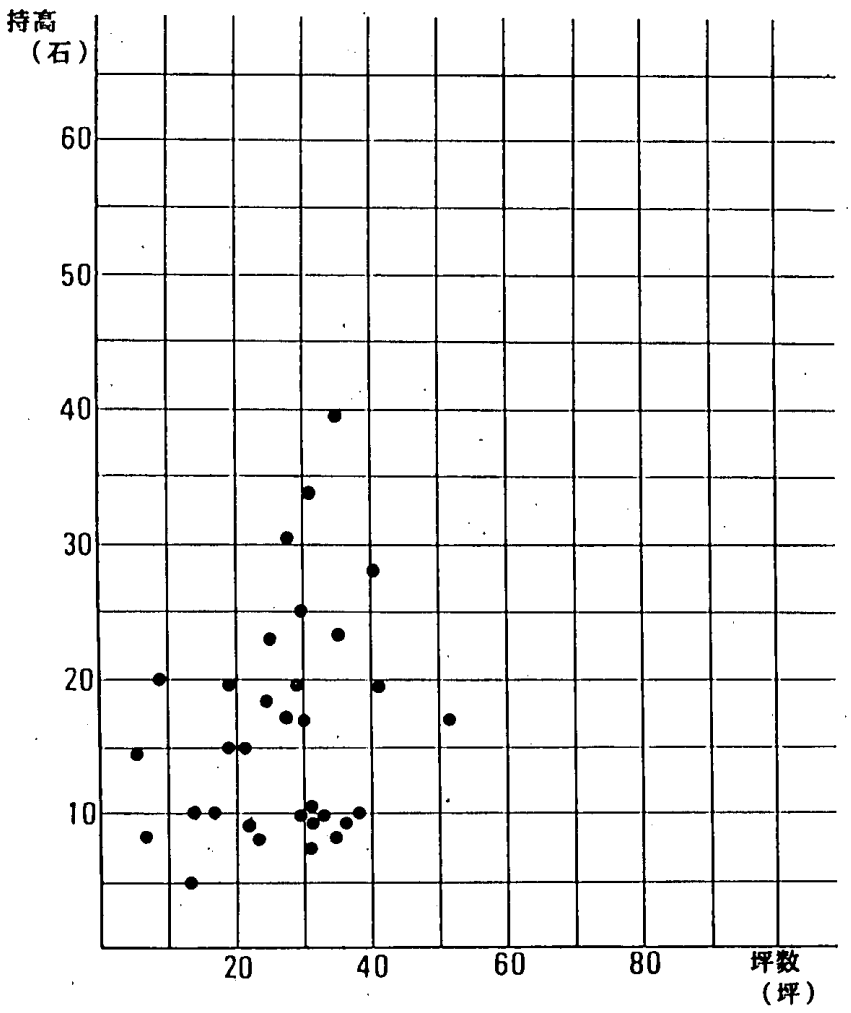

図一12 天保期上横田・屋板村の広間型の主屋規模と持高

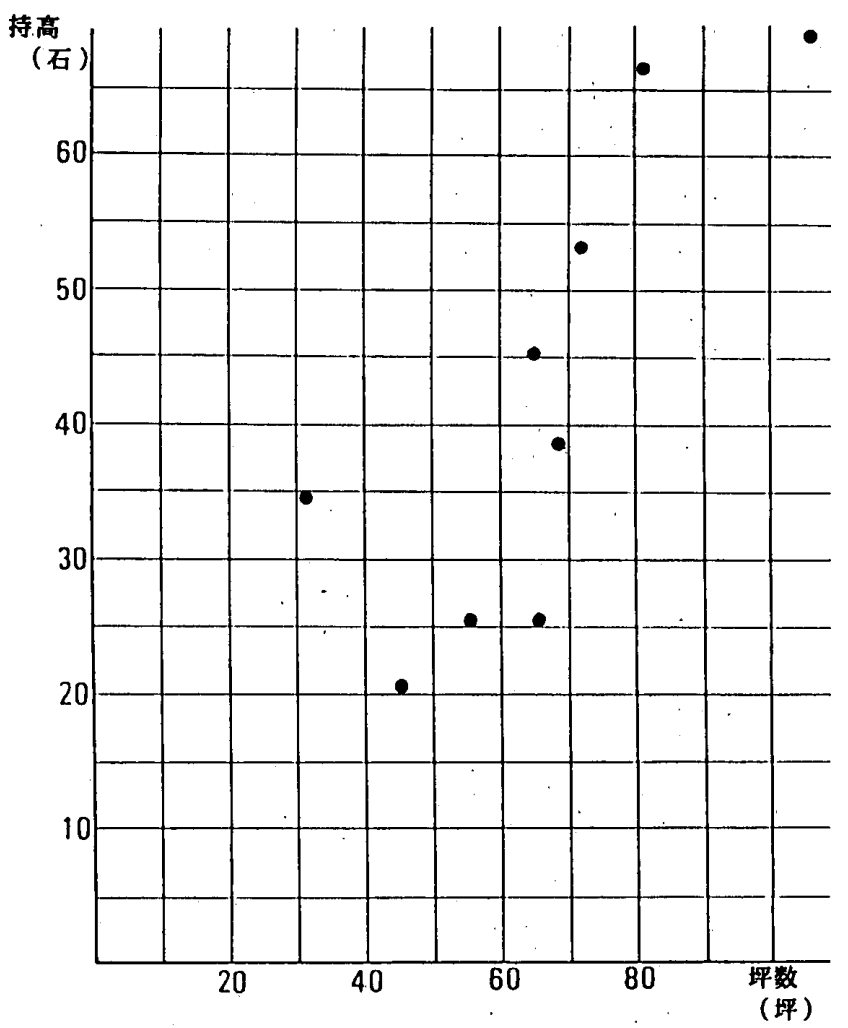

図一13 天保期上横田 ·屋板村の四間取の主屋規模（坪数）之 持高

につれて主屋規模も大きくなる傾向が明らかなのは上金 井村, 上横田・屋板村である。これらの村では, 平均的 に持高の多い上横田・屋板村の方が大きくなる割合が強 い。高谷林新田村は寛文期に開かれており，開かれてか らの年月が浅い関係か比較的規模が集中し, 全体的に規 模の割に持高が少なく, 小さい住居がないのが特徵であ る。その他の村については目立った特徴はみられない。

階層構成と平面形式についてみると, 一間取 ‘二間取 は亭保期一天保期を通じて少数ながら存在し，それらは 持高の少ない層の住居である場合が多い。また, 広間型 は分棟型の床上部分が広間型の場合も含め, 享保期一天 保期の各期を通じて持高の少ない層から多い層まで広く 分布している。喰違四間取・整形四間取などの四間取は 天保期の上横田・屋板村の持高の多い層でみられ, その ほかでは明和期の上金井村の比較的持高の多い 1 軒であ る。土間沿いの広間後側に寝間を設ける四間取は, 文政 期の田中村の中一上の階層で 7 軒みられる。しかし，明 和期の高谷林新田村では最も持高の多い庄屋家 1 軒のみ で，享保期の岩原村では中ほどの階層に 1 軒，また，天 保期の上横田・屋板村では 2 軒が中ほどの階層にみられ るのみである。

\section{2. 家族人数と主屋}

\section{2-1 享保期岩原村の家族人数と主屋}

享保 3 年の『宗門御改帳』より, 享保期の岩原村の各 戸の家族構成がわかる。しかし，住居絵図帳は享保 12 
年であり 10 年の年代差があるためか, 住居絵図帳の 34 軒中 4 軒は, 家族構成が明らかでない。ここでは家族構 成が判明した 30 軒について検討する。なお,『宗門御改 帳』と住居絵図帳との間に 10 年の開きがあるため, 家 族構成に変化があるはずだが，住居は 10 年ほどの間に 急激に変化するとは考えられず, 趨勢把握には支障なく 利用できると考える。

家族人数は, 生屋家が 16 人, 組頭の内の 1 人の家が 11 人と多いが，両家にはそれぞれ 9 人および 4 人の下 人が含まれているためである。そのほかの家は2 8人 である。そのうち，6人家族が最も多く 10 軒あり，7人 家族および 4 人家族の 5 軒が次いで多い。平均家族人数 は 6 人である。

夫婦とその両親および子供夫婦からなる直系家族と叔 父夫婦や戸主の兄弟夫婦などの傍系および下人・前地な ビからなる複合家族に分類すると，直系家族が 21 軒， 複合家族が 9 軒である。複合家族 9 軒のうち下人を置く 家が 4 軒ある。

家族人数と坪数の関係を図一 14 に示す。同じ 6 人家 族でも 12.5 坪から 29 坪と広い幅があるように例外も多 いが，家族人数と主屋坪数とはある程度相関しているよ うである。

家族 1 人当りの主屋坪数は, 最小 2.1 坪, 最大 10.5 坪である。10.5 坪はとびぬけて大きく，家族人数が 2 人と少ないためである。とびぬけて大きい 10.5 坪を別 にすると 1 人当りの坪数は $2.1 \sim 6.5$ 坪に分布しており, 3 坪台に 14 軒が集中している。1 人当り主屋坪数の平均 は 3.6 坪である。

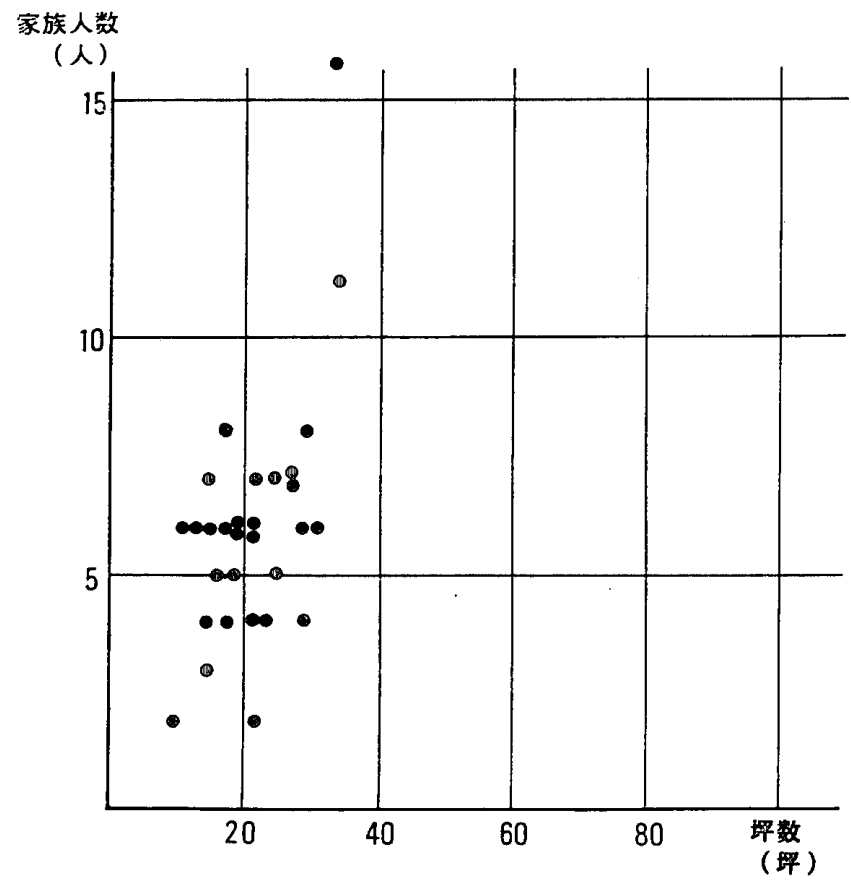

図一14 享保期岩原村の主屋規模（坪数）と家族人数

\section{岩原村家族人数}

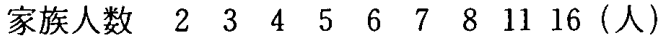

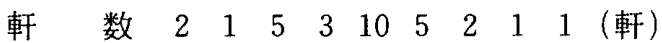

岩原村 1 人当り主屋坪数

坪数 (坪台) $2 \quad 3 \quad 4 \quad 56610$ (坪台)

軒 数 $\quad \begin{array}{lllllll}6 & 14 & 4 & 4 & 1 & 1 \text { (軒) }\end{array}$

\section{2-2 明和期高谷林新田村の家族人数と主屋}

高谷林新田村の明和 6 年の『五人組御改帳』と明和 ? 年の住居絵図帳とを照合して主屋坪数と家族人数の関係 を図一15 に示す。

家族人数は，最小 3 人，最大 8 人である。6 人家族が 最も多く，半数の 6 軒を占めており，平均家族人数も 6 人である。

12 家族のうち，直系家族が 10 軒，複合家族が 2 軒て ある。なお，複合家族に血縁関係のない下人等学含むま のはない。6人家族の 6 軒はそれぞれ 24 坪・ 31.5 坪・ 34 坪・ 35 坪・ 37 坪・ 38.5 坪の主屋に住んでいる。 3 人 家族は当村では最小の 21 坪の主屋に住んでいるが，最 も多人数の 8 人家族の 2 軒は小から中規模の 23 坪 $\cdot 27$ 坪の主屋に住んでいる。以上のように，家族人数と主屋 規模との間に相関はみられない。

1 人当りの坪数は, 最小が 2.9 坪, 最大が 7.45 坪であ る。5〜6.5 坪ほよ゙が多く，半数がこの範囲に入り，平 均 1 人当り坪数は 5.2 坪である。

\section{2-3 文政期田中村の家族人数と主屋}

文政 13 年の『五人組御改帳」より，田中村の各戸の 家族構成がわかる。文政 6 年ごろの住居絵図帳とは6 7 年の年代差があるためか, 24 軒のうち 2 軒は名前が-致しない。家族構成が判明する 22 軒について梌討する。

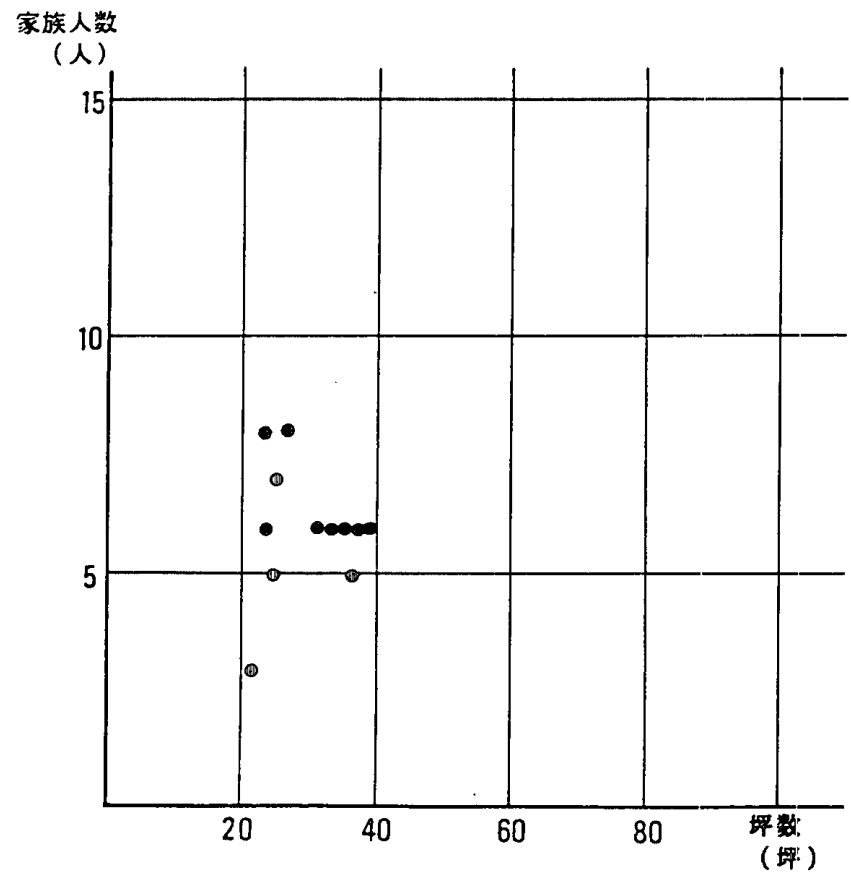

図一15 明和期高谷林新田村の主屋規模（坪数）之家族人数 
家族人数は, 最小 2 人, 最大 10 人である。 4 人 $\cdot 5$ 人 6 人の家族がそれぞれ 4 軒， 7 人・8 8 人家族がそれぞ れ 3 軒ずつで多い。そのほか 9 人が 2 軒あり，10人お よび 2 人がそれぞれ 1 軒である。平均家族人数は 6 人ほ どである。 22 軒のうち, 直系家族が 13 軒で, 複合家族 が 9 軒あり, 他の村に較べ複合家族の占める割合が大き い。また，この複合家族 9 軒には血縁関係がない下人な よ゙を含む例はない。

家族人数と坪数との関係を図一 16 に示す。なお，こ こでは家族人数と住居規模との関係をみるため, 隠居屋 はそれぞれの主屋に加算している。家族人数が最小の 2 人家族の住居が 30 坪あり,また, 同じ 5 人家族であっ ても小は 8 坪, 大は 41 坪の住居であるなど分布の範囲 は広いが，坪数と家族人数とはある程度相関している。

1 人当りの坪数は, 最小 2.9 坪, 最大 15 坪である。 この 15 坪は家族人数が 2 人なので除外すれば $2.9 \sim 7.6$ 坪である。なかでも $3 \cdot 4 \cdot 5$ 坪台が多く 17 軒がこの間 に集中する。平均は 5.3 坪である。

\section{田中村家族人数}

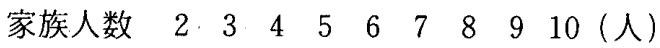

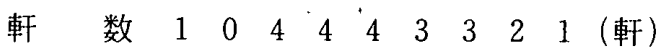

\section{田中村 1 人当り坪数}

坪数 (坪台) $2 \quad 3 \quad 4 \quad 56677$ (坪台)

軒 数 $1.50 \begin{array}{llllll}5 & 5 & 7 & 2 & 1 & 1\end{array}$ (軒)

\section{2-4 上横田・屋板村の家族人数と主屋}

住居絵図帳亡同じ天保 13 年の「宗門御改帳』がある。

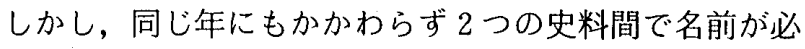
ずしも合致しない。ここでは, 対応関係が明らかな住居 絵図帳の 45 軒中 43 軒について検討する。

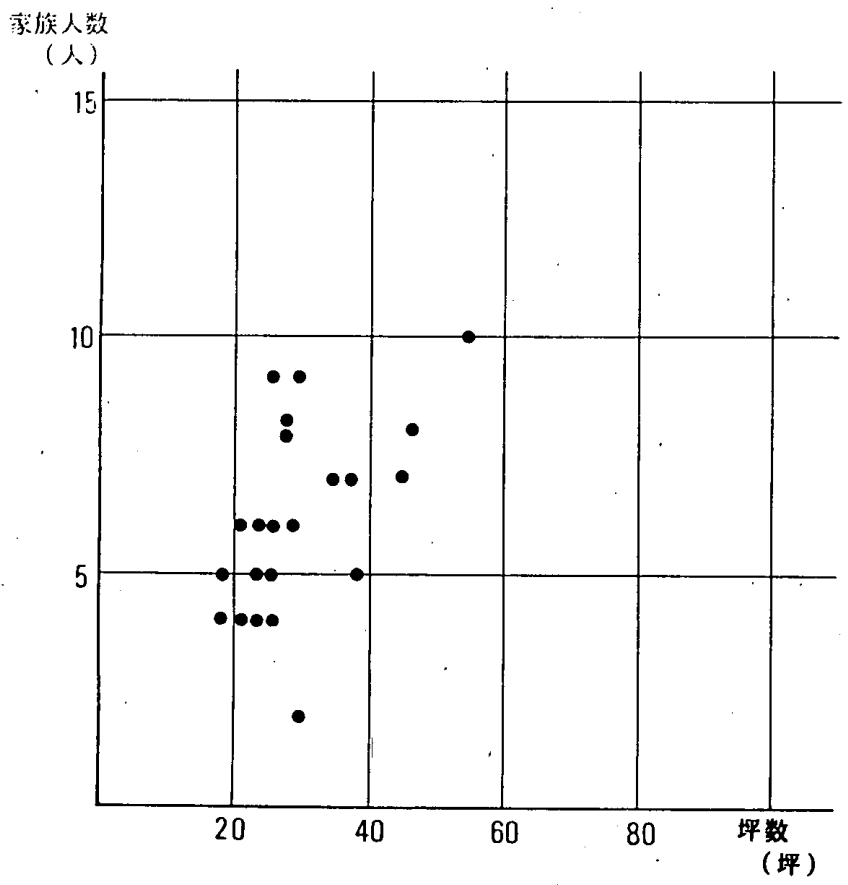

図一16 文政期田中村の主屋規模（坪数）之家族人数
家族人数は，最小 2 人，最大 19 人である。とびぬけ て多い 19 人には，前地の一家 6 人が含まれている。19 人を別にすれば, 2 12人であり，中でも 5 人が 6 軒,

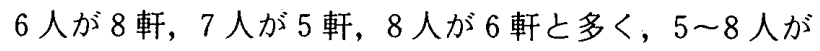
25 軒を占める。平均は 6.7 人である。このうち, 直系 家族が 30 軒, 複合家族が 13 軒で, 13 軒のうち血縁関 係のない前地などを含むのは 19 人の 1 軒だけである。

家族人数と坪数との関係を図一17に示す。なお，こ こでは家族人数と住居規模との関係をみるため, 隠居屋 2 軒はそれぞれの主屋の坪数に加えている。7 人家族で は 7.5 坪から 40 坪を越す場合まであり，家族人数と坪 数との間には強い相関はみられない。

1 人当りの坪数は, 1 人当り 1.25 坪から 19.1 坪まで 極めて幅が広い。1 人当り 2 5 坪台が多く，この間に 27 軒が分布している。平均は 5.9 坪である。また, 8 坪 をこす場合が 10 軒あり，このうち 5 軒は家族人数が 3 人以下のため 1 人当りの坪数が大きくなっている。しか し, 7 人以上であるにもかかわらず 1 人当り坪数が $15: 2$ 坪・9.9 坪・ 8.25 坪ある主屋もある。一方, 1 人当り 3 坪未満も 7 軒ある。すなわち, 当村においては主屋内で 占める 1 人当りの坪数は, 極めて格差が大きい。

\section{上横田・屋板村家族人数}

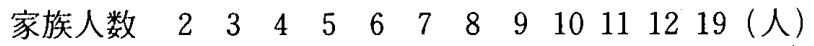

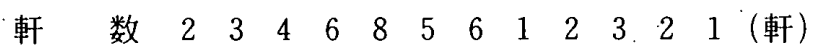

\section{上横田・屋板村 1 人当り主屋坪数}

坪数(坪台) 1234567891011121519 (坪台)

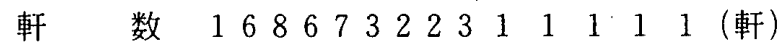
2-5 小 結

家族構成が判明する岩原村, 高谷林新田村, 田中村,

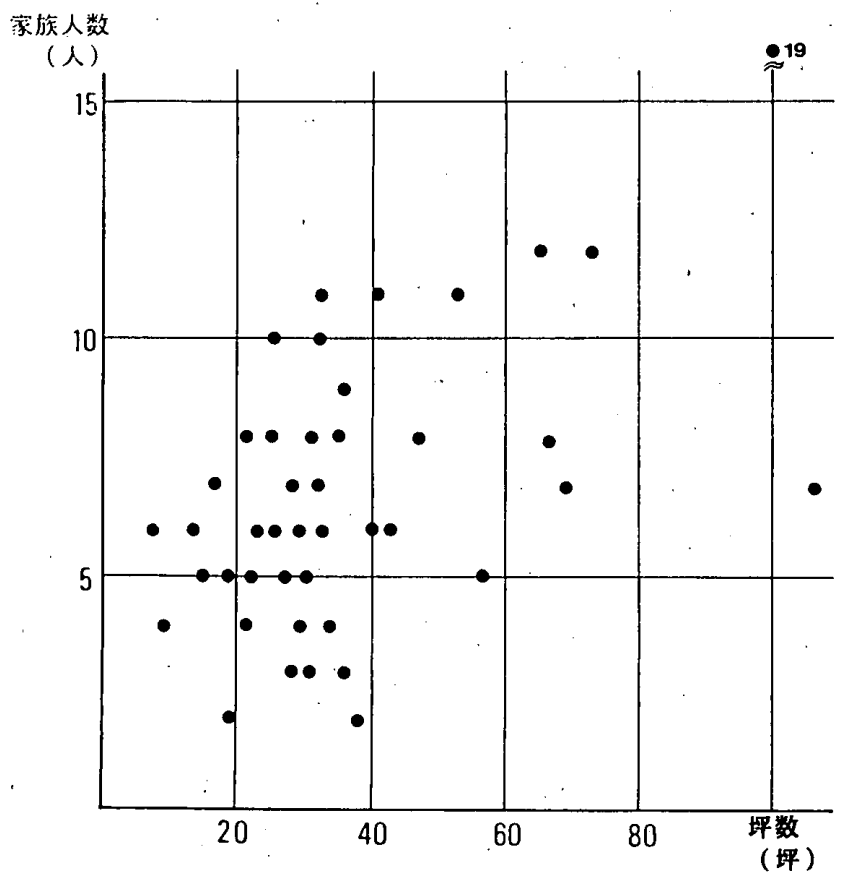

図一17 天保期上横田 $\cdot$ 屋板村の主屋規模（坪数）と家族人数 
上横田・屋板村について家族人数と主屋規模との関係を 検討した。各村・各期を通して概観すれば以下のようで ある。家族人数は, 全般的に 4 - 8 人ほどが多く, 多人 数の家族で 12 人である。一般的百姓家の人数は, 各村 · 各期を通じて 5〜7人ほどとみてよい。血縁親戚でない 下人や前地を含むもので 15 人を越すものが享保期岩原 村・天保期上横田村でそれぞれ 1 軒みられる。

主屋内で占める 1 人当りの坪数の平均は, 検討した 5 村ともに 3 5 坪台が多く，一般的百姓では 5 村の中で 最も古い時期に当たる享保期岩原村では 3.5 坪ほよ゙，そ れ以降の 4 村では 5 6 坪である。その中で, 天保期上 横田・屋板村は平均的には各村と大きな差はみられない が，各戸間の格差が大きくなっている。

家族人数と主屋坪数との関係は, 亭保期の岩原村およ び文政期の田中村においてはある程度相関しているが, それ以外の 2 村では両者の間に強い相関はみられない。

家族人数と主屋坪数との間に相関関係がほとんどない 原因として以下の点が考えられる。当然のことながら家 族の存続期間と主屋の存続期間は必ずしも対応せず, そ れが一因ではあろう。しかし，それ以上に，主屋内に住 む個々人の住空間の確保よりも，村落共同体内部におい て村民間の相互扶助（たとえば結）の確立や家格などに 重きが置かれ，それらが住居を決定する大きな要因に なっているためではないかと考えられる。

ここに, 従来, 江戸時代中・後期においては家族人数 と主屋規模との間には相関関係があまりないであろうと 漠然的に考えられていた点を歴史上再確認することがで きた。

\section{おわりに}

以上, 階層構成と主屋, 家族人数と主屋について検討 した。要約すれば以下の通りである。

階層構成 (持高) と主屋規模との関係は, 持高が増加 するにつれて主屋規模も大きくなる傾向が明らかなのは 明和期の上金井村, 天保期の上横田・屋板村である。こ れらの村では, 平均的に持高の多い上横田・屋板村の方 が大きくなる割合が強い。

享保期の岩原村で 4 割ほどみられる分棟型は, 持高の 多い層に多い。

階層構成と平面形式についてみると，一間取・二間取 は享保期〜天保期を通じて少数ながら存在し，それらは 持高の少ない層に属す場合が多い。広間型は, 享保期一 天保期の各期を通じて持高の少ない層から多い層まで広 く分布している。四間取は天保期の上横田 - 屋板村の持 高の多い層でみられる。

家族人数と主屋についてみると，1 戸当りの家族人数 は, 5〜7人ほどである。1 人当りの坪数の平均は, 享保 期岩原村で 3.5 坪ほど, それ以降の 4 村で 5 〜 坪であ
る。ただし，天保期の上横田・屋板村では各戸間の格差: が大きい。

家族人数と主屋坪数との間には相関はほとんど認めら れない。その原因は，村落共同体内部において村民間の 相互扶助の確立や家格などが住居を決定する大きな要因 であったためではないかと考えられる。

註

1）「日本国語大辞典」(小学館）によると「下宿」は，「した やど：江戸時代，大名などが宿駅の本陣にとまる際，家 臣たちの宿泊する所」とある。

2)拙稿「日光社参史料からみた江戸時代の主屋規模と平面 形式」(日本建築学会計画系論文報告集 第 413 号, 1990 年7月)。

3）前稿に引続き, 日光社参史料のなかで, 村内の住居の平 面を調べて書き上げた絵図帳を住居絵図帳と称し，各村 の住居絵図帳は村名を頭に付けて，たとえば「岩原村住 居絵図帳」のように呼ぶ。なお，史料名・所蔵者名・所 蔵者住所などは前稿に示した通りである。

4）近世における農民層分解については，これまで農民諸個 人の持高別農家階層が指標として使用されてきた。それ は年貢収納が累進税率によらず，農民の持高に応じたも のであったことによる。幕末期, 土地所有と経営が分離し, 地主・小作関係が展開すると, 経営高を知りうる史料も 作成されるが，こうした史料の残存をみない村方におい ては，他に基準にすべき史料を欠き，持高を指標に農民 階層を考察せざるをえないのが, 歴史学研究の現状でも ある点に留意しておきたい。

5）享保 12 年, 「未, 田畑御年貢椠百姓前勘定帳』高橋㟋郎 家文書。

6）「享保三戊戊年，下野国河内郡宇都宮領戸祭筥岩原村宗門 御改帳」高橋悦郎家文書。

7）享保 3 年の宗門帳によれば太郎右衛門の息子として浅右 衛門，伊右衛門が書き上げられている。

8）享保 3 年の宗門帳によれば作左衛門の伯父として権兵衛 が费き上げられている。

9）14 軒の分棟型は，床上部分の平面形式より分類すれば 13 軒が三室広間型およびその三室広間型の背後に裏部屋を 拡張したものである。残る 1 軒は土間沿いの広間後側に 寝間を設ける四間取である。分棟型・非分棟型にかかわ らず床上部分の平面型についてみれば，広間型が 29 軒で ある。

10）「明和八歳霜月, 辛卯田畑御年貢算用帳, 戸祭筋上金井村」 柿沼渉家文書。

11）【延亭五年五月，辰年五人組御改帳」(柿沼渉家文書)，延 享五年の年紀があるが, その後も天明・文化期まで加筆・ 訂正を加えている。

12）「草かき」「草垣」と記されることもあり，秋山地方など で見られた茅壁ではないかと考えられる。

13）持高が多いにもかかわらず，小規模でかつ「草力キ」の 主屋は，あるいは明和 7 年当時すでに建築されて相当年 月を経た主屋ではないかと考えられる。

14）「明和六丑年, 五人組御改帳」山川渉家文書。

15）奥田謙一「寞文・延宝期の宇都宮西原新田の開発」栃木 県史研究第 5 号, 昭和 48 年 3 月所収。 
16）『文政十三庚寅年三月，一野国河内郡宇都宮領戸祭篠田中 村五人組御改帳」池田憲雄家文書。

17）「文政六年三月，户祭篠田中村宗門御改帳」城野正一家文 書。

18）、不明な 2 軒は『五人組御改帳」によると「是八潰百姓」 と註記されており，いずれにせよこの 2 軒（廉蔵・平吉）
は文政 13 年には潰百姓となっている。

19）【弘化三丙丑年, 村方銘々持高滍高書上帳下書, 上横田村」 稲見忠之家文書。

(1990 年 6 月 10 日原稿受理, 1990 年 10 月 16 日採用決定) 